\title{
Soft Computing Approach to Overcome Economic Crisis During COVID-19 Period
}

\author{
Sipali Pradhan', Sujogya Mishra ${ }^{2}$, P. K. Pattnaik ${ }^{3}$ \\ ${ }^{1}$ Dept. of Computer Science, RBVRR Women's College, Hyderabad, India \\ ${ }^{2,3}$ Department of Mathematics and Computing, CET, Bhubaneswar, Odisha
}

\begin{abstract}
The occurrence of COVID-19 brought public and fiscal life to an idle state. In this research work, the thrust is on measuring the impact on affected sectors, such as small-scale industries, small-retail, capital markets, MSMEs. Global and inner mobility are restricted, and the finance generated by journey and sightseeing, which contributes $9.2 \%$ of the Gross domestic product (GDP), will take a major toll on the GDP growth rate. Aviation revenues will come down to a drastically all-time low level. COVID-19 has affected every business sector to reduce their expenses, these sectors adopt the cost-cutting method by which a huge number of employees lost their jobs indirectly affects our state's (Odisha) economic standard. In this work, we adopt a soft computing technique (Rough Set Technique) to find alternative ways to counter the economic crisis.
\end{abstract}

Keywords: Covid-19, Soft Computing, GDP, Economic crisis, Small -Scale industries.

\section{INTRODUCTION}

Covid-19 has affected every sector in our state (Odisha). Measure revenue generating industries are under severe economic crisis. We had taken a survey of over 10,000 people from different parts of our state and using rough set theory [1] [RST] we find a set of alternatives by which we can overcome the crisis. Different researchers had contributed different work shortly mentioned as the effect of COVID-19 on economic in India discuss by Chaudhary et al. [2]. The potential impact of the flu pandemic in Asia discusses by Bloom et al. [3]. Covid-19 and MSMEs: The 'identification' problem discuss by Pandey and Pillai [4]. The Impact of the 1918 Spanish flu on economic performances in Sweden: An investigation into the consequences of an extraordinary mortality shock discuss by Karlsson et al. [5]. The rough set approach in finding the cause of the decline and downfall of jute industries and the remedy discuss by Mishra et al. [6]. Rough set applications for the classification of managerial policies effect on industries discussed by Mishra et al. [7]. Uncertainty analysis of knowledge reductions in rough sets discussed by uncertainty analysis of knowledge reductions in Rough Sets [8]. Coronavirus disease (COVID-19) $[9,10]$ is an infectious disease caused by a newly discovered coronavirus. Mainly people contaminated with the COVID-19 virus will show symptoms of mild to moderate respiratory disorder and get well without any unique treatment. Senior citizens and those with the following health disorder like cardiovascular disease, diabetes, chronic respiratory disease, and cancer are more likely to develop serious illness, which in general develop panic state among the people. The anxiousness of recovering from the COVID-19 situation leads to severe economic crisis especially for small-scale industries, transport industries, and textile industries. In this paper, we are planning to choose several alternatives from the set of possible alternatives by which our state can recover from the state of economic crisis to achieve this we use Rough set theory [11], using this concept we can choose the exact number of conditional attributes from the large set of conditional attributes.

\section{MATHEMATICAL MODEL FOR DATA ANALYSIS}

In this paper, we use RST as our mathematical tool for attribute reductions. The idea of RST is given by Pawlak (1982). This theory develops very fast since then and a wide number of applications. Rough Set theory uses three basic concepts such as Decision Table, Conditional attributes, Decision attributes.

Representation of rough set is represented by $\langle E, R, D\rangle$, where $\mathrm{E}$, set of Records, $\mathrm{R}$, set of conditional attributes and $\mathrm{D}$, set of decision attributes.

A skeleton of the Rough set is given in the following table.

Table.1. Decision Table

\begin{tabular}{|l|l|l|}
\hline $\mathrm{E}$ & $\mathrm{R}$ & $\mathrm{D}$ \\
\hline $\mathrm{E}_{1}$ & $\mathrm{r}_{1}$ & $\mathrm{~d}_{1}$ \\
\hline $\mathrm{E}_{2}$ & $\mathrm{r}_{2}$ & $\mathrm{~d}_{2}$ \\
\hline $\mathrm{E}_{3}$ & $\mathrm{r}_{3}$ & $\mathrm{~d}_{3}$ \\
\hline
\end{tabular}




\section{International Advanced Research Journal in Science, Engineering and Technology}

Vol. 8, Issue 6, June 2021

\section{DOI: $10.17148 / I A R J S E T .2021 .8640$}

Basic ideas of RST and shows how these ideas may be used for data mining. Universally, the rough set theory may be applied to data without conflict to study the association between attributes.

\section{BASICS OF ROUGH SET}

i. Lower Approximation:

$B^{\prime}=\cup\{R \in E / B: R \subset X\}$, called as $B^{\prime}-$ Lower.

ii. Upper Approximation:

$B^{*}=\cup\{R \in E / B: R \cap X=\varphi\}$, called as $B^{*}-$ Upper.

iii. Indiscernibility in rough set-Indiscernibility is an important concept in the rough set defined as a relation between two or more objects, where all the values are identical concerning a subset of considered attributes. This relation is equivalence in nature.

iv. Reduct:

if $\mathrm{A} \subset \mathrm{A}^{\prime}$ are two different rough sets such that,

Indiscernibility $(A)=$ Indiscernibility $\left(A^{\prime}\right)$.

v. Core:

Define as $\bigcap$ Reduct

\section{EXAMPLE OF ROUGH SET}

We may remove superfluous attributes. Another characteristic task is to find the least subset of the attribute set that may be used to recognize all concepts. Yet another job is to figure a family of sets of attribute-value pairs for the same reason: to identify all concepts. Inconsistent data sets are handled by rough set theory using lower and upper approximations for every concept. These methods are definable using active attributes. Furthermore, from concept of lower and upper bound approximations, definite and possible rule sets are generated. Another vital area of rough set theory applications is imperfect data, i.e., data with attribute missing values. Here rough set theory may be used, again, for computing generalized lower and upper approximations for all concepts. In this work, we will restrict our attention to only one technique of data mining rule induction.

\section{DATA ANALYSIS PHASE -I}

We had collected data from various parts of our state. Major thrust being given on small-scale industries and employees depending on the private sector for their live hood. The data are presented in the following tables.

Table. 2. Initial Table (Survey)

\begin{tabular}{|c|c|c|c|c|}
\hline District & $\begin{array}{c}\text { Entertainment } \\
\text { industries }\end{array}$ & $\begin{array}{c}\text { Agricultural } \\
\text { Sector }\end{array}$ & $\begin{array}{c}\text { Employee depending on } \\
\text { Private sector }\end{array}$ & Total \\
\hline Kandhamal & 45000 & 40000 & 15000 & 90,000 \\
\hline Bolangir & 40000 & 65000 & 5000 & 110,000 \\
\hline Koraput & 35000 & 35000 & 2000 & 9000 \\
\hline
\end{tabular}

Table. 3. Renaming of the conditional attributes and decision attributes

\begin{tabular}{|l|c|c|c|c|c|}
\hline Conditional attribute & $\begin{array}{c}\text { Rename of } \\
\text { Conditional } \\
\text { attributes }\end{array}$ & $\begin{array}{c}\text { Values of } \\
\text { Conditional } \\
\text { attributes }\end{array}$ & $\begin{array}{c}\text { Renaming values } \\
\text { of Conditional } \\
\text { attributes }\end{array}$ & $\begin{array}{c}\text { Decision } \\
\text { attributes } \\
\text { (D) }\end{array}$ & $\begin{array}{c}\text { Renaming values } \\
\text { of Decision } \\
\text { attribute }\end{array}$ \\
\hline $\begin{array}{l}\text { Every business sector should adopt } \\
\text { an online procedure }\end{array}$ & 11 & Significant & $\begin{array}{l}\text { Note } \\
\text { able }\end{array}$ & aa \\
\hline $\begin{array}{l}\text { Private educational institute should } \\
\text { adopt proper online education }\end{array}$ & 22 & Insignificant & qq & Pointless & bb \\
\hline $\begin{array}{l}\text { Information about the goods for } \\
\text { common people should properly } \\
\text { communicate on a common website }\end{array}$ & 33 & & & & \\
\hline $\begin{array}{l}\text { Use of online methods should } \\
\text { available to common people with } \\
\text { affordable price }\end{array}$ & 44 & & & & \\
\hline
\end{tabular}


DOI: $10.17148 / I A R J S E T .2021 .8640$

\begin{tabular}{|l|l|l|l|l|l|}
\hline $\begin{array}{l}\text { Central Government should be taken } \\
\text { care of all, Excluding Education }\end{array}$ & 55 & & & & \\
\hline $\begin{array}{l}\text { Idea of mobile hospital should be } \\
\text { implemented in all states }\end{array}$ & 66 & & & & \\
\hline
\end{tabular}

\subsection{Algorithm to find Reduct:}

for $R\left(\mathrm{X} \mathrm{Y} \mathrm{Z} \mathrm{W)} \mathrm{and} \begin{array}{l}F D=\{X Y Z \rightarrow W \\ X Y \rightarrow Z W, X \rightarrow Y Z W\}\end{array}\right.$

where $X, Y, Z$ are conditional attributes, their dependencies represent by FD

if

$X Y+=X Y Z W$

(from the method we studied earlier)

$X Y$ is a reduct

finding the closure is applicable for all possible combination of two conditional attributes

else

$X Y Z+=X Y Z W$

$\left(X Y Z^{+}\right.$is the closure of $X Y Z$ )

$X Y Z$ is a reduct

finding the closure is applicable for all possible combination of three conditional attributes

terminate the procedure.

In this case, we have considered only 4 -attributes so the process terminates after finding 3 -conditional attributes combination.

Finding the equivalence class can be extended in finding (n-1) reduct set for $\mathrm{n}$-dimensional space.

\section{DATA ANALYSIS PHASE-II}

For this work, we have considered 6-alternatives to give a boost to our economic backbone. The alternatives are represented in the following table.

Table. 4.

\begin{tabular}{|c|c|c|c|c|c|c|c|}
\hline $\mathbf{E}$ & $\mathbf{1 1}$ & $\mathbf{2 2}$ & $\mathbf{3 3}$ & $\mathbf{4 4}$ & $\mathbf{5 5}$ & $\mathbf{6 6}$ & $\mathbf{D}$ \\
\hline $\mathrm{E}_{1}$ & $\mathrm{pp}$ & $\mathrm{pp}$ & $\mathrm{pp}$ & $\mathrm{pp}$ & $\mathrm{pp}$ & $\mathrm{pp}$ & $\mathrm{aa}$ \\
\hline $\mathrm{E}_{2}$ & $\mathrm{qq}$ & $\mathrm{qq}$ & $\mathrm{qq}$ & $\mathrm{qq}$ & $\mathrm{qq}$ & $\mathrm{qq}$ & $\mathrm{bb}$ \\
\hline $\mathrm{E}_{3}$ & $\mathrm{pp}$ & $\mathrm{qq}$ & $\mathrm{pp}$ & $\mathrm{qq}$ & $\mathrm{pp}$ & $\mathrm{qq}$ & $\mathrm{bb}$ \\
\hline $\mathrm{E}_{4}$ & $\mathrm{pp}$ & $\mathrm{pp}$ & $\mathrm{pp}$ & $\mathrm{qq}$ & $\mathrm{qq}$ & $\mathrm{qq}$ & $\mathrm{aa}$ \\
\hline $\mathrm{E}_{5}$ & $\mathrm{pp}$ & $\mathrm{pp}$ & $\mathrm{qq}$ & $\mathrm{qq}$ & $\mathrm{pp}$ & $\mathrm{pp}$ & $\mathrm{aa}$ \\
\hline $\mathrm{E}_{6}$ & $\mathrm{qq}$ & $\mathrm{qq}$ & $\mathrm{pp}$ & $\mathrm{qq}$ & $\mathrm{pp}$ & $\mathrm{pp}$ & $\mathrm{bb}$ \\
\hline
\end{tabular}

With the above conditional and decision attributes, we had considered approximately 200,000 records and by using correlation techniques we had only 6-dissimilar records. The dissimilar records are given below after renaming.

\section{DATA ANALYSIS PHASE-III}

Finding Indiscernibility relation denoted as IND (conditional attribute).

$$
\begin{aligned}
& I N D(11)=\left\{\left\{E_{1}, E_{3}, E_{4}, E_{5}\right\},\left\{E_{2}, E_{6}\right\}\right\}, \\
& I N D(22)=\left\{\left\{E_{1}, E_{4}, E_{5}\right\},\left\{E_{2}, E_{3}, E_{6}\right\}\right\}, \\
& I N D(33)=\left\{\left\{E_{1}, E_{3}, E_{4}, E_{6}\right\},\left\{E_{2}, E_{5}\right\}\right\}, \\
& I N D(44)=\left\{\left\{E_{1}\right\},\left\{E_{3}, E_{4}, E_{6}, E_{2}, E_{5}\right\}\right\}, \\
& I N D(55)=\left\{\left\{E_{1}, E_{3}, E_{5}, E_{6}\right\},\left\{E_{2}, E_{4}\right\}\right\}, \\
& I N D(66)=\left\{\left\{E_{1}, E_{5}, E_{6}\right\},\left\{E_{2}, E_{3}, E_{4}\right\}\right\} .
\end{aligned}
$$




\section{DOI: $10.17148 / I A R J S E T .2021 .8640$}

$$
\begin{aligned}
& \operatorname{IND}(11,22)=\left\{\left\{E_{1}, E_{4}, E_{5}\right\},\left\{E_{2}, E_{6}\right\},\left\{E_{3}\right\}\right\}, \\
& \operatorname{IND}(11,33)=\left\{\left\{E_{1}, E_{3}, E_{4}\right\},\left\{E_{2}\right\},\left\{E_{5}\right\},\left\{E_{6}\right\}\right\}, \\
& \operatorname{IND}(11,44)=\left\{\left\{E_{1}\right\},\left\{E_{3}, E_{4}, E_{5}\right\},\left\{E_{2}, E_{6}\right\}\right\}, \\
& I N D(11,55)=\left\{\left\{E_{1}, E_{3}, E_{5}\right\},\left\{E_{2}\right\},\left\{E_{4}\right\},\left\{E_{6}\right\}\right\}, \\
& I N D(11,66)=\left\{\left\{E_{1}, E_{5}\right\},\left\{E_{2}\right\},\left\{E_{3}, E_{4}\right\},\left\{E_{6}\right\}\right\} \text {. } \\
& \operatorname{IND}(22,33)=\left\{\left\{E_{1}, E_{4}\right\},\left\{E_{2}\right\},\left\{E_{3}, E_{6}\right\},\left\{E_{5}\right\}\right\}, \\
& \operatorname{IND}(22,44)=\left\{\left\{E_{1}\right\},\left\{E_{2}, E_{3}, E_{6}\right\},\left\{E_{4}, E_{5}\right\}\right\} \text {, } \\
& \operatorname{IND}(22,55)=\left\{\left\{E_{1}, E_{5}\right\},\left\{E_{2}\right\},\left\{E_{3}, E_{6}\right\},\left\{E_{4}\right\}\right\}, \\
& \operatorname{IND}(22,66)=\left\{\left\{E_{1}, E_{5}\right\},\left\{E_{2}, E_{3}\right\},\left\{E_{4}\right\},\left\{E_{6}\right\}\right\} \text {. } \\
& \operatorname{IND}(33,44)=\left\{\left\{E_{1}\right\},\left\{E_{2}, E_{5}\right\},\left\{E_{3}, E_{4}, E_{6}\right\}\right\} \text {, } \\
& \operatorname{IND}(33,55)=\left\{\left\{E_{1}, E_{3}, E_{6}\right\},\left\{E_{2}\right\},\left\{E_{4}\right\}\left\{E_{5}\right\}\right\}, \\
& \operatorname{IND}(33,66)=\left\{\left\{E_{1}, E_{6}\right\},\left\{E_{2}\right\},\left\{E_{3}, E_{4}\right\},\left\{E_{5}\right\}\right\} \text {. } \\
& \operatorname{IND}(44,55)=\left\{\left\{E_{1}\right\},\left\{E_{4}, E_{2}\right\},\left\{E_{3}, E_{5}, E_{6}\right\}\right\}, \\
& \operatorname{IND}(44,66)=\left\{\left\{E_{1}\right\},\left\{E_{4}, E_{2}, E_{3}\right\},\left\{E_{5}, E_{6}\right\}\right\} . \\
& \operatorname{IND}(55,66)=\left\{\left\{E_{1}, E_{5}\right\},\left\{E_{4}, E_{2}\right\},\left\{E_{3}\right\}\left\{E_{5}, E_{6}\right\}\right\} \text {. } \\
& \operatorname{IND}(11,22,33)=\left\{\left\{E_{1}, E_{4}\right\},\left\{E_{2}\right\},\left\{E_{3}\right\},\left\{E_{5}\right\},\left\{E_{6}\right\}\right\}, \operatorname{IND}(22,33,44)=\left\{\left\{E_{1}\right\},\left\{E_{2}\right\},\left\{E_{3}, E_{6}\right\},\left\{E_{4}\right\},\left\{E_{5}\right\}\right\}, \\
& \begin{array}{l}
\operatorname{IND}(11,22,44)=\left\{\left\{E_{1}\right\},\left\{E_{2}, E_{6}\right\},\left\{E_{4}, E_{5}\right\},\left\{E_{3}\right\}\right\}, \quad I N D(22,33,55)=\left\{\left\{E_{1}\right\},\left\{E_{2}\right\},\left\{E_{3}, E_{6}\right\},\left\{E_{4}\right\},\left\{E_{5}\right\}\right\}, \\
I N D(11,22,55)=\left\{\left\{E_{1}, E_{5}\right\},\left\{E_{2}\right\},\left\{E_{4}\right\},\left\{E_{6}\right\},\left\{E_{3}\right\}\right\},
\end{array} \\
& I N D(11,22,66)=\left\{\left\{E_{1}, E_{5}\right\},\left\{E_{2}\right\},\left\{E_{4}\right\},\left\{E_{6}\right\},\left\{E_{3}\right\}\right\} . \\
& \operatorname{IND}(33,44,55)=\left\{\left\{E_{1}\right\},\left\{E_{2}\right\},\left\{E_{3}, E_{6}\right\},\left\{E_{4}\right\},\left\{E_{5}\right\}\right\}, \\
& \operatorname{IND}(33,44,66)=\left\{\left\{E_{1}\right\},\left\{E_{2}\right\},\left\{E_{3}, E_{4}\right\},\left\{E_{5}\right\},\left\{E_{6}\right\}\right\} . \\
& \operatorname{IND}(11,22,33,44)=\left\{\left\{E_{1}\right\},\left\{E_{2}\right\},\left\{E_{3}\right\},\left\{E_{4}\right\},\left\{E_{5}\right\},\left\{E_{6}\right\}\right\}, \\
& \operatorname{IND}(44,55,66)=\left\{\left\{E_{1}\right\},\left\{E_{2}, E_{4}\right\},\left\{E_{3}\right\},\left\{E_{5}, E_{6}\right\}\right\} . I N D(11,22,33,55)=\left\{\left\{E_{1}\right\},\left\{E_{2}\right\},\left\{E_{3}\right\},\left\{E_{4}\right\},\left\{E_{5}\right\},\left\{E_{6}\right\}\right\}, \\
& \operatorname{IND}(11,22,33,66)=\left\{\left\{E_{1}\right\},\left\{E_{2}\right\},\left\{E_{3}\right\},\left\{E_{4}\right\},\left\{E_{5}\right\},\left\{E_{6}\right\}\right\} . \\
& \operatorname{IND}(22,33,44,55)=\left\{\left\{E_{1}\right\},\left\{E_{3}, E_{6}\right\},\left\{E_{2}\right\},\left\{E_{4}\right\},\left\{E_{5}\right\}\right\}, \\
& \operatorname{IND}(22,33,44,66)=\left\{\left\{E_{1}\right\},\left\{E_{2}\right\},\left\{E_{3}\right\},\left\{E_{4}\right\},\left\{E_{5}\right\},\left\{E_{6}\right\}\right\}, \\
& \operatorname{IND}(33,44,55,66)=\left\{\left\{E_{1}\right\},\left\{E_{2}\right\},\left\{E_{3}\right\},\left\{E_{4}\right\},\left\{E_{5}\right\},\left\{E_{6}\right\}\right\} .
\end{aligned}
$$

The classes $\langle 32,33,34,36,28>$ form the reduct space as these equivalence classes were providing distinct result and these classes are given below:

32.(11, 22, 33, 44), 33.(11, 22, 33, 55), 34.(11, 22, 33, 66) ,36.(22,33, 44, 66), 28.(22, 33, 66).

As above, 5 cases provide 6-distinct cases are taken initially so we have 5 sets of the reduct:

Core $=\bigcap\{(11,22,33,44),(11,22,33,55),(11,33,55,66),(22,33,44,66),(22,33,66)\}=33$

Now the attribute 33 is the most essential attribute as it is present in every reduct set next we consider one of the reduct classes among the 5 reduct class for further analysis $<11,22,33,44>$.

Now we are finding the strength [12] of the reduct space the strength was

$e(11)_{p p}(a a)=75 \%, e(11)_{q q}(a a)=0 \%, e(11)_{p p}(b b)=25 \%, e(11)_{q q}(b b)=100 \%$. 


\section{International Advanced Research Journal in Science, Engineering and Technology}

Vol. 8, Issue 6, June 2021

\section{DOI: $10.17148 / I A R J S E T .2021 .8640$}

From the above calculation, one can ensure that 11 is essential. Similarly from the calculation, $e(22)_{p p}(a a)=100, e(22)_{q q}(b b)=100 \%$.

It is confirmed that, 22 is essential

Now 33 is essential as it is the core. For 44 attributes $(a a)$ present once in its value only bb values are present so we can safely remove attribute 44 from the following tables.

Table. 5. Reduct I

\begin{tabular}{|l|l|l|l|l|l|}
\hline $\mathbf{E}$ & $\mathbf{1 1}$ & $\mathbf{2 2}$ & $\mathbf{3 3}$ & $\mathbf{4 4}$ & $\mathbf{D}$ \\
\hline $\mathrm{E}_{1}$ & $\mathrm{pp}$ & $\mathrm{pp}$ & $\mathrm{pp}$ & $\mathrm{pp}$ & $\mathrm{aa}$ \\
\hline $\mathrm{E}_{2}$ & $\mathrm{qq}$ & $\mathrm{qq}$ & $\mathrm{qq}$ & $\mathrm{qq}$ & $\mathrm{bb}$ \\
\hline $\mathrm{E}_{3}$ & $\mathrm{pp}$ & $\mathrm{qq}$ & $\mathrm{pp}$ & $\mathrm{qq}$ & $\mathrm{bb}$ \\
\hline $\mathrm{E}_{4}$ & $\mathrm{pp}$ & $\mathrm{pp}$ & $\mathrm{pp}$ & $\mathrm{qq}$ & $\mathrm{aa}$ \\
\hline $\mathrm{E}_{5}$ & $\mathrm{pp}$ & $\mathrm{pp}$ & $\mathrm{qq}$ & $\mathrm{qq}$ & $\mathrm{aa}$ \\
\hline $\mathrm{E}_{6}$ & $\mathrm{qq}$ & $\mathrm{qq}$ & $\mathrm{pp}$ & $\mathrm{qq}$ & $\mathrm{bb}$ \\
\hline
\end{tabular}

Table. 6. Reduct II

\begin{tabular}{|l|l|l|l|l|}
\hline $\mathbf{E}$ & $\mathbf{1 1}$ & $\mathbf{2 2}$ & $\mathbf{3 3}$ & $\mathbf{D}$ \\
\hline $\mathrm{E}_{1}$ & $\mathrm{pp}$ & $\mathrm{pp}$ & $\mathrm{pp}$ & $\mathrm{aa}$ \\
\hline $\mathrm{E}_{2}$ & $\mathrm{qq}$ & $\mathrm{qq}$ & $\mathrm{qq}$ & $\mathrm{bb}$ \\
\hline $\mathrm{E}_{3}$ & $\mathrm{pp}$ & $\mathrm{qq}$ & $\mathrm{pp}$ & $\mathrm{bb}$ \\
\hline $\mathrm{E}_{4}$ & $\mathrm{pp}$ & $\mathrm{pp}$ & $\mathrm{pp}$ & $\mathrm{aa}$ \\
\hline $\mathrm{E}_{5}$ & $\mathrm{pp}$ & $\mathrm{pp}$ & $\mathrm{qq}$ & $\mathrm{aa}$ \\
\hline $\mathrm{E}_{6}$ & $\mathrm{qq}$ & $\mathrm{qq}$ & $\mathrm{pp}$ & $\mathrm{bb}$ \\
\hline
\end{tabular}

Rules are derived as follows:

1. if $<11,22,33>$ values are $p p$ then the decision is aa,

2. if $<11,22,33>$ values are qq then the decision is bb,

3. if $<11,33>$ values are pp and 22 value is qq then the decision is $b b$,

4. if $<11,22>$ values are pp and 33 values is qq then the decision is bb.

\section{ANALYSIS OF ECONOMIC GROWTH RATE}

The growth rate can be explained by the differential Eqns. (1) \& (3). Pre-COVID-19 economic condition of our state is presented in Eqn. (1) and post-COVID-19 economic condition of our state is presented in Eqn. (2). These equations with its solutions are presented below:

$\frac{d y_{1}}{d t} \alpha y_{1}, \quad y_{1}(0)=10,000$

where $y_{1}$, economic growth pre-COVID-19

$\Rightarrow y_{1}=e^{t+4}$.

$\frac{d y_{2}}{d t} \alpha\left(-y_{2}\right), \quad y_{2}(0)=100$

where $y_{2}$, economic growth post-COVID-19

$\Rightarrow y_{2}=e^{-t+2}$.

The two effective solutions, Eqns. (2) \& (4) are presented graphically in Figs. (1) \& (2). It is seen that, both the growth rates are exponential in nature. Fig. 1 shows the exponential enhancement of economic growth of our country preCOVID-19, which is excepted because our country is a growing country. Fig. 2 shows the exponential decrement of economic growth of our country post COVID-19, which can be seen in the present scenario of our country India. This figure witnesses a drastic change to the economic condition unless it is stopped. 
DOI: $10.17148 /$ IARJSET.2021.8640

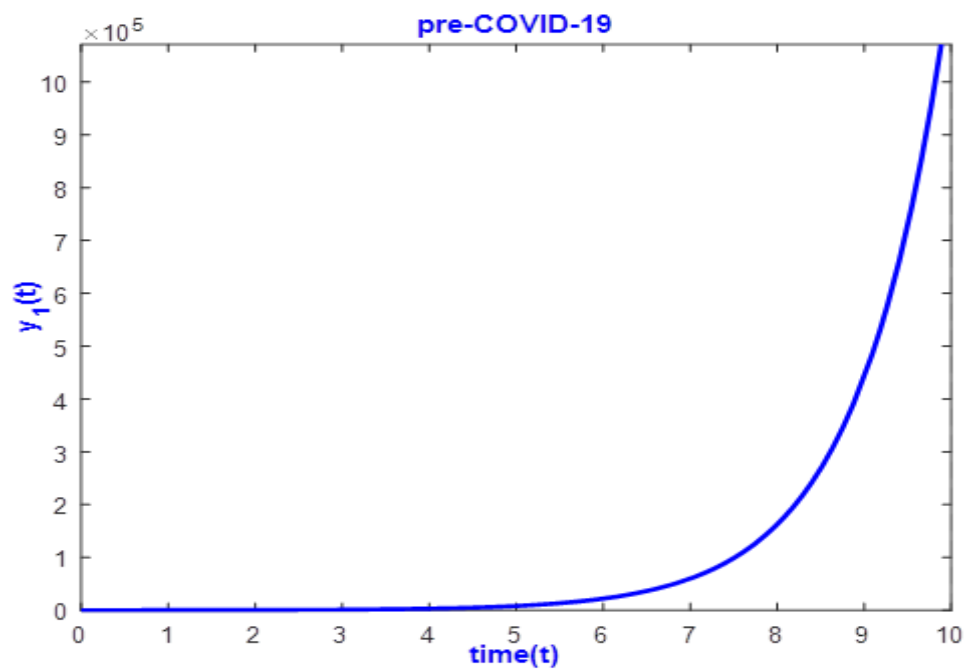

Fig. 1. Growth Rate of Economic Condition

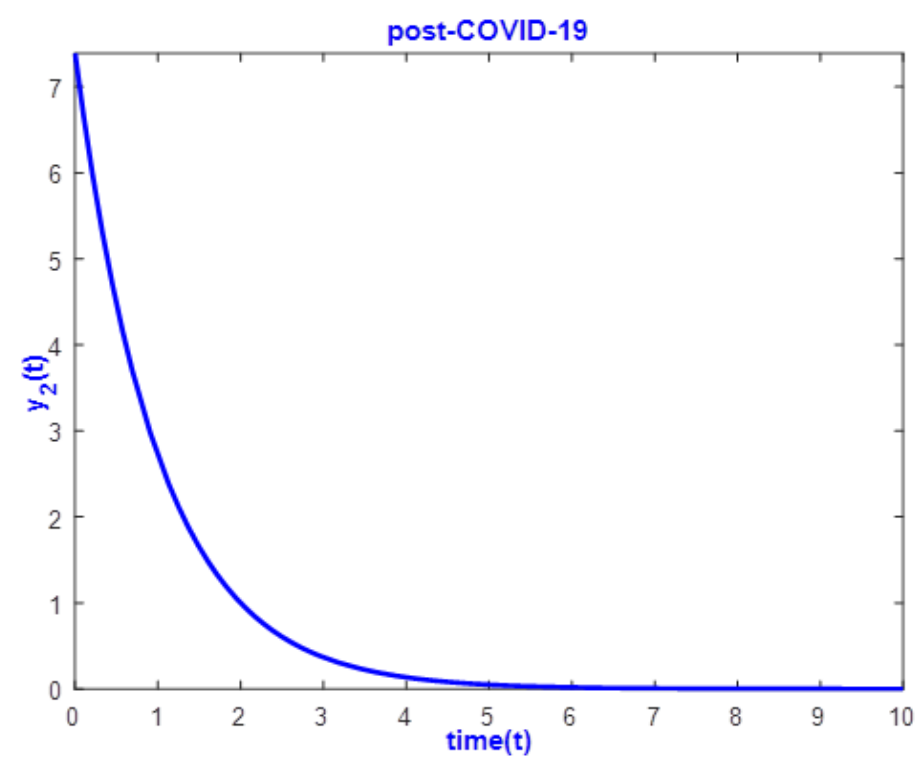

Fig. 2. Growth Rate of Economic Condition

\section{SIMULATION AND VALIDATION OF THE RESULT}

To validate our claim we choose the Chi-square test [12], this test is non-parametric. The non-parametric test doesn't follow a particular distribution. As our samples are heterogeneous and don't follow any distribution so we choose the Chi-square test to validate our claim.

$\mathrm{H}_{0}$ (Null Hypothesis):

The attribute $<11,22,33>$ i.e. every business sector should adopt the online procedure, the private educational institute should adopt proper online education, information about the goods for common people should properly communicate in a common website are not essential alternatives in the growth of the economy of our state (Odisha)

$\mathrm{H}_{1}$ (Alternative Hypothesis):

The attributes $<11,22,33>$ are essential in the economic growth of our state.

For Chi-square test we had taken 10 observed samples from the original survey as $35,25,15,45,65,75,5,85,95$, and 55 and expected samples for 10 days given by $10 \%, 10 \%, 5 \%, 10 \%, 15 \%, 15 \%, 2 \%, 15 \%, 20 \%$, and $10 \%$.

So the expected samples are 50, 50, 25, 50, 75, 75, 10, 75, 100 and 50.

So, calculated Chi-square value,

$\chi_{C}^{2}=\sum_{i} \frac{\left(\mathrm{E}_{\mathrm{i}}-\mathrm{O}_{\mathrm{i}}\right)^{2}}{\mathrm{E}_{\mathrm{i}}}=14.47$ 


\section{International Advanced Research Journal in Science, Engineering and Technology}

Vol. 8, Issue 6, June 2021

\section{DOI: $10.17148 / I A R J S E T .2021 .8640$}

whereas tabulated Chi-square value,

$\chi^{2}(9,0.95)=3.325$

Since $\chi_{C}^{2}>\chi_{T}^{2}$, so we reject the null hypothesis and accept the alternate hypothesis. The attributes $<11,22,33>$ are essential alternatives attribute in the economic growth of our state, which can be implemented to enhance the economic power.

\section{CONCLUSION}

We must expect minimum 5 years from now (COVID-19) will exit in our country and if we will not planned our economic properly then entire country going to suffer a huge economic crisis. The plans are that to use the conditional attributes $<11,22,33,44,55,66>$ as,

$\{(11,22,33,44),(11,22,33,55),(11,22,33,66),(22,33,44,66),(22,33,66)\}$

This implementation can stop the continuous decrement shown in Fig. 2 which results the economic behaviour to an exponential growth as shown in Fig. 1.

\section{FUTURE SCOPE}

This work can be extended to find the expected growth rate of COVID-19 and total economic destruction of the world during this period. So that we should be prepared to handle the economic crisis during the pandemic.

\section{REFERENCES}

[1] Pawlak, Z. (1982). Rough sets, International Journal of Computer \& Information Sciences, 11(5), pp.341-356.

[2] Chaudhary, M., Sodani, P.R., Das, S. (2020). Effect of COVID-19 on Economy in India: Some Reflections for Policy and Programme, Journal of Health Management, 22 (2).

[3] Bloom, E., Wit, V. de. Jose, M.J.C.S. (2005). Potential economic impact of an Avian Flu Pandemic on Asia. ERD Policy Brief, Economics and Research Department, Series No. 42, pp.1-14.

[4] Pandey, R., Pillai, A. (2020). Covid-19, and MSMEs: The 'identification' problem, IDEAS FOR INDIA, https://www.ideasforindia.in/topics/macroeconomics/covid-19-and-the-msme-sector-the-identification-problem.html.

[5] Karlsson, M., Nilsson, T., Pichler, S. (2014). The Impact of the 1918 Spanish flu epidemic on economic performance in Sweden: An investigation into the consequences of an extraordinary mortality shock, Journal of Health Economics, 36.

[6] Mishra, S., Mohanty, S.P., Pradhan, S.K., Hota, R. (2015). Rough Set Approach in Finding the Cause of Decline and Down Fall of Jute Industries and the Remedy, International Journal of Computer Applications, 121(19), pp.35-41.

[7] Das, R., Mishra, D., Mishra, S. (2017). Rough Set Applications for the Classification of Managerial Policies Effect on Industries, International Journal of Computer Applications, 180(6), pp.1-4.

[8] Wang, Y. Zhang, N. (2014). Uncertainty Analysis of Knowledge Reductions in Rough Sets, Scientific World Journal, pp.1-8. doi.org/10.1155/2014/576409

[9] Ouassou, H., Kharchoufa, L., Bouhrim, M., Daoudi, N.E., Imtara, H., Bencheikh, N., Bouzidi, A.E.L., Bnouham, M. (2020). The Pathogenesis Corona Virus Diseases-2019 (COVID-19) Evolution, and Prevention, Journal of Immunology Research. doi:10.1155/2020/1357983

[10] Singhal, T. (2020). A Review of Coronavirus Disease-2019 (COVID-19), The Indian Journal of Pediatrics, 87(4), pp.281-286. doi: $10.1007 / \mathrm{s} 12098-020-03263-6$

[11] Vashist, R., Garg, M.L. (2011). Rule Generation based on Reduct and Core A Rough Set Approach, International Journal of Computer Application, 29(9), pp.1-5.

[12] J. L. Devore, "Probability and Statistics for Engineering and the Sciences", $8^{\text {th }}$ Ed ${ }^{\text {n }}$, Cengage Learning, (2012). 